新しい茶種苗の供給体制と種苗法について

独立行政法人 農業- 食品産業技術総合研究機構

野菜茶業研究所*

根角厚司

\title{
Newly Supply System of Tea Cultivars and an Outline of the Seeds and Seedlings Low on Tea
}

\author{
Atsushi Nesumi \\ National Institute of Vegetable and Tea Science \\ National Agriculture and Food Research Organization
}

\section{1 はじめに}

わが国の茶育種の歴史を遡ると、明治時代初 頭に行われた多田元吉による海外遺伝資源の 導入にたどり着く ${ }^{1)}$ 。その後、栘山彦三郎に 代表される多くの民間育種家や国・府県など 公的研究機関が品種改良を行い、その結果今 では、わが国で育成された品種は100を越え ている（別表 $1 \sim 7$ ）。しかし、現在わが国
の全茶園面積の約 8 割を ‘やぶきた’一品種 が占めているのが現状であり ${ }^{2)}$ 、労働の集中 化、病虫害の多発、香味の画一化など、一品 種勔占状態による多くの弊害が生じている。 ‘やぶきた'の栽培面積が急速に増加したの は1965年以降のことであり 2)（図 1 ）、現在、 多くの茶園が改植時期にさしかかっているこ とから、計画的な改植が必要になっている。 一方、近年の健康志向の高まりや緑茶ドリ

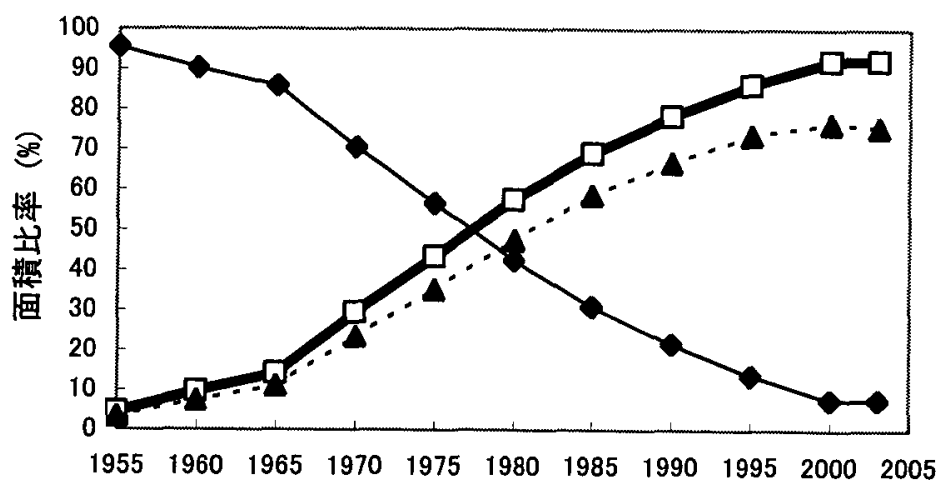

図 1 品種化率の推移

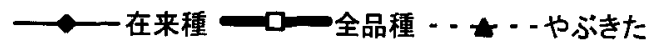

(社団法入日本茶業中央会 平成18年度茶関係資料より) 
ンクの需要の急增により、国内における茶の 消費量は伸びている。そして、㖺好や用途の 多様化、安全・安心への要求の高まりなどか ら、新しい品種への期待も高まっている。

これまで、永年生作物である茶において、 栽培している茶樹を改植して新品種に切り替 えることは容易ではなかった。しかし、・ゃ ぶきだの古い茶園が改植時期にさしかかっ た今、新品種への期待は高まっており、新品 種種苗の需要は増大している。そのような状 況下で、新品種の種苗がなかなか入手できな いあるいは海外に日本で育成された新品種 が流出するなどの問題も生じており、種苗の 供給体制の見㨁しや、種苗法の周知と遵守へ の取り組みが必要となった。

独立行政法人農業・食品産業技術総合研究 機構（以下、農研機構）野菜茶業研究所では、 2005年に種苗法の一部改正や、2005年度から の独立行政法人種苗管理センター（以下、種 苗管理センター）の茶原種苗配布事業の終了 （原種穗の配付業務は移行措置として2006年 度まで行う）を受けて、茶新品種の許諾と原 種穂の配布方法について関係機関と協議を行 い、農研機構が育成者権を有する茶品種につ いての許諾契約の方法および原種穂の供給体 制の変更を行った。

ここでは、新しい種苗法の骨子と、農研機 構における新たな茶品種の許諾および種苗の 供給体制について解説する。

\section{2 種苗法}

種苗法は、新品種の保護のための品種登録 に関する法律で、品種育成の振興と種苗流通 の適正化により農林水産業を発展させること を目的とした法律である(種苗法第 1 条)。 1978年に種苗法が制定されるまで、わが国で は1947年に公布された農産種苗法に基づき、 不良種苗の取り締まりと優良種苗育成の助長 を行ってきた。しかし、1978年に改正された 植物の新品種の保護に関する国際条約
(UPOV条約：Union internationale pour la pro-tection des obtentions vegetales) に加 盟するため、その内容に適合するように整備 された。UPOV条約は1991年にも改正されて おり、わが国の種苗法もそれに合わせて、 1998年に全面改正を行い、その後は情勢の変 化に応じて法律の一部が改正されてきた。最 近では違法に持ち出された新品種の種苗が育 成者権者に無断で利用され、その収穫物が加 エされてわが国に輸入されるという問題に対 応するため、2005年6月17日に種苗法施行令 の一部が改正され（政令第348号）、同年12月 1日から施行された。改正内容の要点は以下 の二つである。一つ目は、加工品への㕕成者 権の効力の拡大であり、茶（葉または茎を製 茶したもの）、小豆（豆を水煮したもの（砂 糖を加えたものを含む）及びあん）、いぐさ (ござ)、稲（米飯）がこれに指定された。二 つ目は、育成者権の存続期間の延長であり、 茶や果樹など永年生植物では25年を30年、そ の他の植物では 20 年を 25 年へと延長された。 したがって、育成者権のある品種については、 正規の種苗を用いて国内で生産された加工品 については問題にはならないが、違法性のあ る種苗から生産された加工品については国内 生産であっても種苗法違反となることに注意 する必要がある。

\section{3 種苗法に違反した場合の周則}

種苗法に違反した場合、以下のような藅則 が適用される。(1)刑事罰として、個人に対し ては 3 年以下の懲役又は300万円以下の罰金、 法人では 1 億円以下の罰金、(2)民事上の請求 として、(1)損害賠償請求、(2)侵害行為した種 苗や収穫物の海外への生産・販売等の差し止 め請求、(3)無断利用によって権利者が被った 信用の低下を回復するための措置の請求など である。

以前は、茶の品種識別が難しく、違法性の 
証明は困難であった。しかし、最近ではD N $\mathrm{A}$ 鑑定による品種識別技術が確立され 3.4 、 微量元素による原産国の推定もある程度の精 度で可能となり、関税法による育成者権を侵 害した物品に対する輸出入の差し止め請求を 行うことにより、輸出入品に対しても水際で 食い止めることが可能になってきた。

\section{4 茶新品種に関する許諾契約の方法}

これまで農研機構が育成者権を有する茶品 種については、各府県で指定された代表団体 から申請があった場合に、農研機構が品種ご とに許諾契約を結んでいた（図 2)。そして、 多くの種苗生産者は、許諾を結んだ代表団体 の傘下に入り、取り扱い実績の報告を代表団 体に対して行う方式をとってきた。しかし、 この方法では、(1)代表団体が許諾契約を結ん でいない品種の取り扱いができない、(2)代表 団体が府県単位の組織の場合、府県をまたが った流通が制限される可能性がある、(3)代表 団体の傘下に入ることができなければ新品種 の種苗を扱うことができない等の問題が生じ ていた。そこで、2006年度からは、公的な機 関や団体、あるいは種苗生産グループ、個人 に対して、農研機構が一定の要件（業として の種苗生産、これまでの販売実績、信頼性、 等）を満たしていると認めた者は、申請があ れば許諾契約を結ぶことができることとした (図 3)。これまでにすでに許諾を結んでいる 団体については、契約解除の申請がないかぎ り、従来通りの内容でそのまま継続されるこ ととなる。また、本年度から許諾申請先は、 農研機構本部総合情報管理部知的財産セン夕 ーに対して行うこととなったため、種苗の販 売額に応じて支払う許諾利用料については、 農研機構本部総合情報管理部知的財産セン夕 一に確認する必要がある。なお、これまでに 一件でも許諾契約を結んでいる品種の場合、 その品種の利用料率は、新規の許諾申請者に 対しても最初に定められた利用料率が適用さ
れる。許諾契約を結んだ種苗生産者は、野菜 茶業研究所のホームページや各府県への連絡 文書、商業誌等に、希望しない場合を除き公 表する予定である。

\section{5 種苗管理センターによる原種苗配布業務 の終了と新たな原種穂供給体制}

これまでの茶種苗の流通は、阡諾契約を結 んだ代表団体が県知事を通して地方農政局に 対し採穂園設置場所の申告と茶原種の配布申 請を行い、農政局は種苗管理センターに対し て、原種苗の配付要請をすることになってい た。その結果、種苗管理センターから申請を 出した団体に対して原種苗が配布され、配布 を受けた団体は採穂園を設置し、そこから傘 下の種苗生産者に苗木生産用の穂を供給する というシステムとなっていた（図 2 )。しか し、2005年度をもって種苗管理センターがそ の業務を終了することとなったため、原種穂 の配布を育成場所である野菜茶業研究所（金 谷茶業研究拠点および枕崎茶業研究拠点) で 行うことになった（図 3 )。前述したとおり、 2006年度は移行措置として種苗管理センター 知覧農場が原種穂の供給をすることになって いるが、2007年度からは野菜茶業研究所で原 種穂の配布を行うため、新たに農研機構と許 諾契約を結ぶ時には、採穂園用の原種穂を野 菜茶業研究所に対して申請する必要がある。 原種穂はあくまで採穂園用であるので、一件 あたり100本程度を限度とし（申請者数に応 じて変動有り）、有償で配付することを予定 している。ただし、育成者権の切れた品種に ついてはこの限りではない。

\section{6 すでに流通した無許諾苗およびその生産 物の取り扱いについて}

前述したとおり、新しい種苗法では、育成 者権を侵害した種苗で生産された加工品につ いても育成者権の侵害と見なされ、種苗法違 反となる。自家増殖が容易な茶では、無許諾 


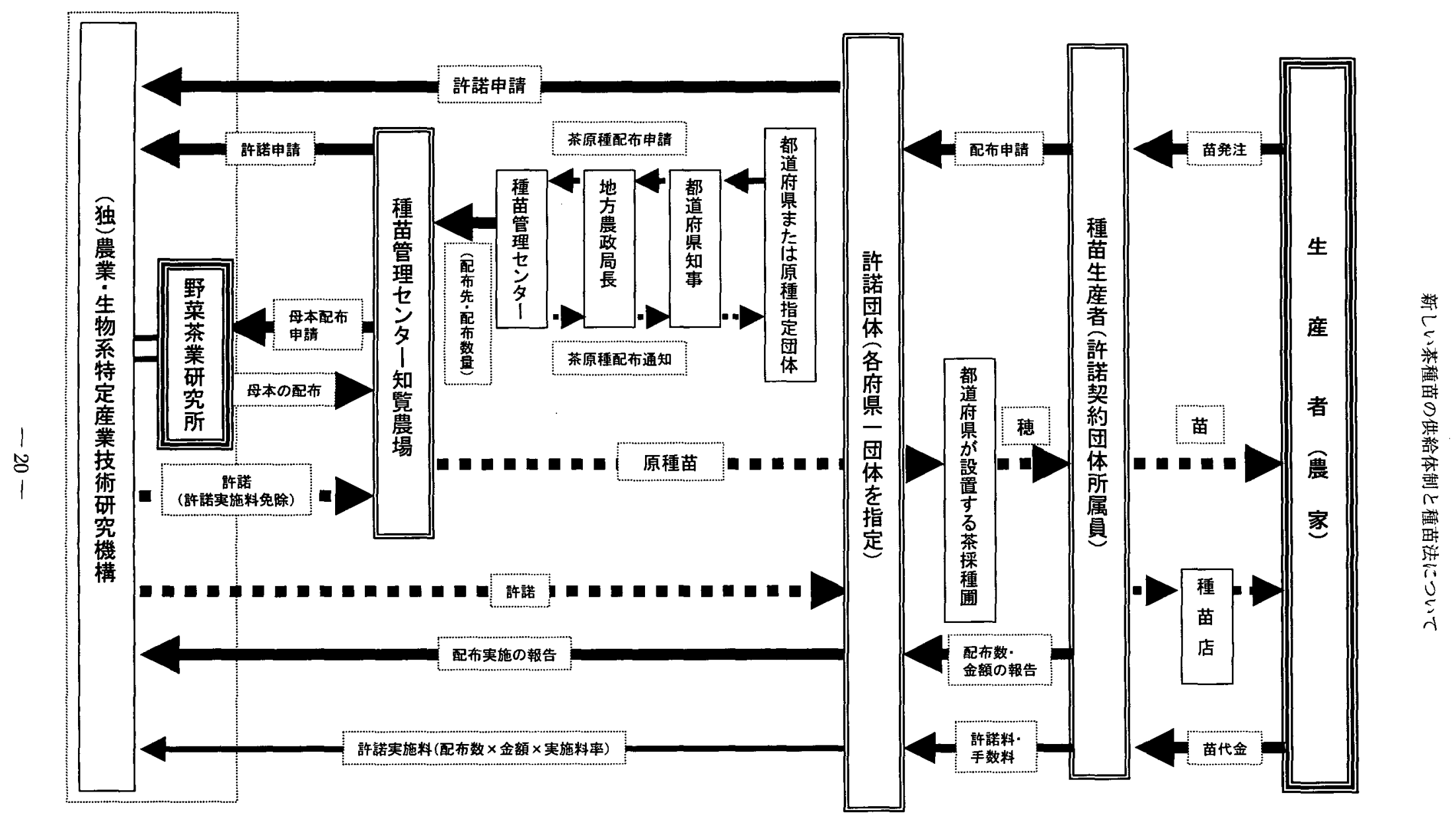

図2 これまでの（独）農研機構育成品種における許諾の方法と種苗の流れ 


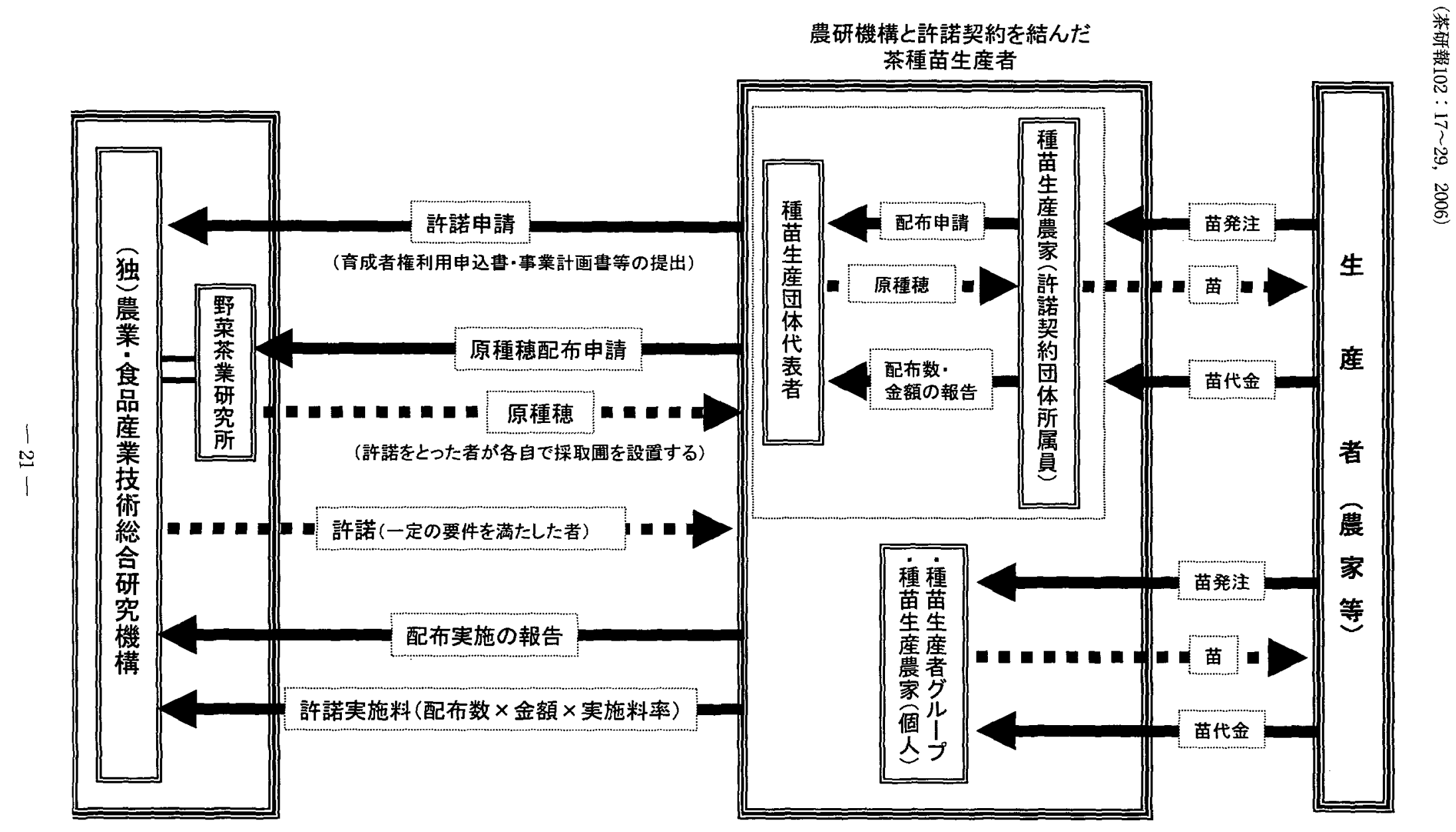

四 3 これまでの（独〉農呼機構奆成品種における許諾の方法と種苗の流れ 
で流通した新品種の種苗も多いと言われる が、これは種苗法が十分に理解されていない ことが大きな要因と考えられる。しかしなが ら、安心・安全への関心が高まる中、トレー サビリティーへの対応も進んでおり、今後、 違法種苗から生産された茶の取引を控えよう とする動きも出ており、違法種苗で流通した 状態のまま放置することは、生産者にとって も大きな問題となる可能性がある。そこで、 これまで違法とは知らないで新品種の種苗を 生産、販売してしまった種苗生産者は、すみ やかに許諾申請を行い、過去に種苗生産に用 いた母樹が当該品種であることをD N A 鑑定 で証明した書類を示し、遡って許諾実施料を 支払うことで、過去に違法性のあった種苗を 正規の種苗と見なす救済策を検討中である。 ただし、無許諾で育成者権のある種苗を生 産・販売し、今後も許諾申請を行わない場合 は、種苗法違反として取り締まりの対象とな る。また、生産者が流通業者や消費者から、 生産している新品種の茶種苗が違法性のない ものである証明を求められた場合は、正規の 種苗業者から購入したことがわかる書類等を 提示しなくてはならない。

なお、D N A鑑定は以下の機関に依頼して 行うことができる。

機関名：（財）日本食品分析センター千歳研 究所

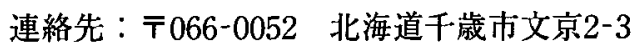

（電話番号：0123-28-5911）

\section{7 自家增殖について}

自家増殖は、本来育成者の権利を侵害する ものであるが、わが国では従来から農業者の 慣行として行われてきたことに鑑み、一定の 要件の下で、育成者権者の許諾を得ずに収穫 物を種苗に転用することが認められている (種苗法第21条第 2 項)。ただし、契約で別段 の定めをしたとき、および農林水産省令で定 める栄養繁殖をする植物に属する品種の種苗
を用いる場合は自家増殖はできない（種苗法 第21条第 3 項)。茶の場合、自家增殖は許さ れているが、増殖した種苗を他人に販売した り譲渡してはならない。言うまでもなく、元 になる種苗は正規に入手したものでなくては ならない。また、正規の種苗であっても、有 償、無償にかかわらず、育成者権者の許可無 く国外に持ち出すことは厳禁である。

\section{8 なぜ種苗法を守らなくてはいけないのか}

茶は容易に自家增殖できるため、一度普及 し始めると、無許諾の種苗がいつの間にか出 回り、育成者の権利が侵害されていることあ る。苗の生産者も、種苗法に関する知識がな い場合、自家増殖の延長線と考える人も少な からずいると思われる。

しかし、品種の育成には長い年月が必要で あり、チャでは 20 年以上の歳月と、多くの人 がかかわって品種ができあがる。このように 有成された品種を違法に生産・販売すること は、育成者の権利を侵害し、品種開発の発展 を阻害するものである。種苗法では、育成者 権が消滅していない場合、この権利は「登録 品種の種苗の生産、又は当該種苗を調整する 行為、譲渡の申出、譲渡、輸出、翰入、若し くはこれらの行為をする目的をもって保管す る行為に対して効力が及ぶ」とされており (種苗法第21条第 1 項)、䏍成者に無断で生産、 販売を行うことだけでなく、無断で譲渡した り、国外へ持ち出す行為も禁止されている。

最近、イチゴ、カーネーション、イグサ、 柑橘など多くの農産物で、国内で育成された 品種が国外で栽培され、違法に日本で販売さ れ、国内の生産者に損害を与えるといった問 題が生じている。チャにおいても、国内の新 品種が国外で生産されれることは、国内茶産 業に大きな損害を与える可能性を秘めている ことを承知しておく必要がある。 


\section{9 許諾申請の方法}

農研機構が育成した茶品種 (命名登録品種) の許諾申請は、これまでは各県毎に一つにま とめて、農研機構へ申請されていた。しかし、 今後は個別の団体や個人でも申請が可能とな ったこと、2006年に農研機構が組織再編を行 ったことに伴い、新たに許諾を得たい者が、 独立行政法人農業・食品産業技術総合研究機 構本部総合情報管理部知的財産センターに申 請することとなった。

農研機構本部総合情報管理部知的財産セン ターに対して新たに許諾申請を行う時は、野 菜茶業研究所に対しても原種穂の配付申請と 採穂園設置場所の申告を行う必要がある。野 菜茶業研究所は、農研機構本部総合情報管理 部知的財産センターから利用許諾締結の通知 を受けてから、原種穂の提供を行う事となっ ている。

許諾申請先、原種穂の配付申請及び育成品
種の問い合わせ先は下記の通りである。

【許諾申請先】

機関名：独立行政法人農業・食品産業技術総 合研究機構本部総合情報管理部知的 財産センター種苗係

連絡先：テ305-8517 茨城県つくば市観音台 3-1-1（電話番号：029-838-7390、F AX番号：029-838-8905)

【農研機構が育成者権を有するチャ品種の原 種穂の配付申請先及び問い合わせ先】

機関名：野菜茶業研究所企画管理部業務推進 室運営チーム

連絡先：テ514-2392 三重県津市安濃町草生 360 （電話番号：052-268-4623）

機関名：野菜茶業研究所金谷茶業研究拠点茶 育種グループ

連絡先： $\mathbf{T} 428-8501$ 静岡県島田市金谷2769 （電話：0547-45-4101）

表 1 育成者権のある命名登録品種と育成者

\begin{tabular}{|c|c|c|c|c|c|c|}
\hline 品種名 & 農林登録番号 & 登録年月日” & 登録番号 & $\begin{array}{c}\text { 登録の } \\
\text { 有效期限 }\end{array}$ & $\begin{array}{c}\text { 育成者権の } \\
\text { 満了日 }\end{array}$ & 育成者権者名 ${ }^{2)}$ \\
\hline しゅんめい & 茶農林37号 & $1990 / 4 / 3$ & 第2159号 & 18年 & $2008 / 4 / 3$ & 農研機棲 \\
\hline みねかおり & 茶農林38号 & $1990 / 4 / 3$ & 第2157号 & 18年 & $2008 / 4 / 3$ & 宮崎県 \\
\hline みなみかおり & 茶農林39号 & $1990 / 4 / 3$ & 第2158号 & 18年 & $2008 / 4 / 3$ & 宮崎県 \\
\hline さえみどり & 茶震林40号 & $1991 / 11 / 19$ & 第2881号 & 18年 & $2009 / 11 / 19$ & 農研機構 \\
\hline ふうしゅん & 茶農林41号 & $1993 / 10 / 13$ & 第3697号 & 18年 & $2011 / 10 / 13$ & 農研機構 \\
\hline みなみさやか & 茶農林42号 & $1994 / 3 / 14$ & 第3932号 & 18年 & $2012 / 3 / 14$ & 宮崎県 \\
\hline ほくめい & 茶農林43号 & $1995 / 11 / 8$ & 第4775号 & 18年 & $2013 / 11 / 8$ & 埼玉県 \\
\hline ベにふうき & 茶農林44号 & $1995 / 8 / 17$ & 第4591号 & 18年 & $2013 / 8 / 17$ & 農研機構 \\
\hline りょうふう & 茶農林45号 & $2001 / 8 / 16$ & 第9204号 & 25年 & $2026 / 8 / 16$ & 農研機構 \\
\hline むさしかおり & 茶農林46号 & $2001 / 10 / 12$ & 第9306号 & 25年 & $2026 / 10 / 12$ & 埼玉県 \\
\hline さきみどり & 茶農林47号 & $2001 / 8 / 16$ & 第9203号 & 25年 & $2026 / 8 / 16$ & 宮崎県 \\
\hline はるみどり & 茶農林48号 & $2003 / 3 / 17$ & 第11102号 & 25年 & $2028 / 3 / 17$ & 農研機構 \\
\hline そうふう & 茶農林49号 & $2005 / 2 / 7$ & 第12706号 & 25年 & $2030 / 2 / 7$ & 農研機構 \\
\hline さいのみどり & 茶農林50号 & $2006 / 2 / 27$ & 第13753号 & 30年 & $2036 / 2 / 27$ & 埼玉県 \\
\hline はるもえぎ & 茶農林51号 & $2006 / 2 / 27$ & 第13755号 & 30年 & $2036 / 2 / 27$ & 宮崎県 \\
\hline みやまかおり & 茶農林52号 & $2006 / 2 / 27$ & 第13754号 & 30年 & $2036 / 2 / 27$ & 宮崎県 \\
\hline ゆめわかば & 茶農林53号 & 出願中 & & & & 埼玉県 \\
\hline ゆめかおり & 茶農林54号 & 出願中 & & & & 宮崎県 \\
\hline
\end{tabular}

1) 登録年:種苗法に基づく品種登録年月日

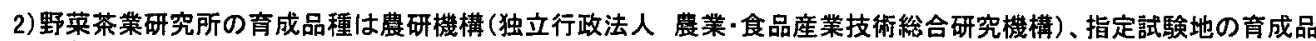
種は各場所の所在県が育成者権を有する。 
機関名：野菜茶業研究所枕崎茶業研究拠点茶 育種グループ

連絡先：=898-0087 鹿児島県枕崎市瀬戸町 87 (電話番号：0993-76-2126)

なお、国費による茶の育種事業は野菜茶業 研究所だけでなく、茶育種指定試験地である 埼玉県農林総合研究センター茶業特産研究所 および宮崎県総合農業試験場茶業支場におい も行われている。これらの場所で育成された 品種（命名登録品種）に関する問い合わせ空 口は以下の通りである。

機関名：埼玉県農林部生産振興課品種登録 · 種苗センター

連絡先：=330-9301 埼玉県さいたま市浦和 区高砂3-15-1（電話番号：048-830-4198）

機関名：宮崎県総合農業試験場茶業支場育種 科

連絡先：干889-1301 宮崎県児湯郡川南町大 字川南 17070 （電話番号：0983-27-0 355)

農研機構および指定試験地が育成した品種 で、育成者権が存在する品種を表1に示す。

育成者権が切れた品種に関しては、その取 り扱いは自由である。しかし、増殖が容易で 見分けのつきにくい茶に扔いては、一旦間違 った品種名で流通したり、他品種が混ざった 状態で流通すると大きな混乱のもとになるの で、古い品種であっても種苗の取り扱いに際 しては十分な注意が必要である。

\section{0 おりに}

付加価值が高く、多くの国で栽培され、世 界的に流通する茶は、18世紀にはすでに国際 競争の中にあった。アメリカ独立戦争の導火 線となったボストン茶会事件（1773年）や列 強による中国の植民地化のもととなったアへ ン戦争（1840１842年）など、茶が世界史を
摇るがす大事件にも関与していたことはあま りにも有名な史実である゙”。19世紀には、い くつかの生産国において、優良な産地からの 種子の導入が始まっており、このころすでに 品種の重要性が認識され始めている。

わが国においても、1876年に元幕臣であっ た多田元吉が中心となって、中国より種子を 購入、持ち帰って以来、海外遺伝資源の導入 や品種改良が続けられてきた6)。

近年、機能性成分高含有品種として注目さ れている ‘ベにふうき'は、多田がインドよ り導入した系統の実生から選抜された ‘゙に ほまれ’ (茶農林 1 号) が片親に使われてい る。したがって、‘べにふうき’が品種登録 (1995年、命名登録は1993年) され、現在の ように機能性成分が注目されるようになるま でには、遗伝資源の収集、保存、評価、それ を用いての品種育成、その後の機能性の解明 や栽培法、加工法の改良など、実に多くの関 係者が関わっている。このような品種が、海 外に流出し、その結果日本向けに逆輸入され るようなことになれば、育成者の権利が侵害 されるだけでなく、わが国の茶産業にとって も大きな損失となることは言うまでもないこ とである。

最近では多様化した需要に応えるため、 様々な育種目標をかかげて品種改良が進めら れている。国内茶産業を守り、消費者の二ー ズにも迅速に応えるためは、新しい種苗法と 種苗の流通体制の下、品種の健全かつ速やか な普及が望まれる。

\section{1 謝辞}

本稿の作成にあたり、貴重なアドバイスを いただいた、野菜茶業研究所企画管理部業務 推進室の若松正文氏、農研機構本部総合情報 管理部知的財産センターの白石恵子さんに深 く感謝申し上げます。 


\section{2 引用文献}

1）川口国昭（1997）: 茶業開化-明治発展史 と多田元吉. 山童社, 東京, $\mathrm{pp} 72-194$.

2）社団法人日本茶業中央会（2006）：平成 18 年版茶関係資料.社団法人日本茶業中 央会, 東京, 24 .

3 ) Kaundun,S.S., Matsumoto, S. (2003) : Identification of processed Japanese green tea based on polymorphisms generated by STS-RFLP analysis. Journal of Agricultural and Food Chemistry, 51: 7, 1765-1770.

4) Kaundun,S.S., Matsumoto,S. (2003): Development of CAPS markers based on three key genes of the phenylpropanoid pathway in tea, Camellia sinensis (L.) O.Kuntze, and differentiation between assamica and sinensis varieties. Theoretical and Applied Genetics, $106: 3,375-383$.

5 ）松崎芳郎（1992）: 年表茶の世界史. 八坂書房, 東京, $\mathrm{pp} 138-154$.

6) 武田善行 (2004)：茶のサイエンス. 筑波書房, 東京, pp38-40.

\section{3 参 考 情 報}

本稿に関連する情報についてWeb上で公 開されている主なURLを下記に示す。

1）財団法人日本食品分析センター http://www.jfrl.or.jp/

2）茶の新品種の取扱いに関する Q \& A（野 菜茶業研究所)

http://vegetea.naro.affrc.go.jp/QandA/ QandA.htm

3 ) 農研機構の知的財産（農研機構知的財産 センター)

http://www.naro.affrc.go.jp/patent/

4 ）品種登録情報（農林水産省生産局種苗課） http://www.hinsyu.maff.go.jp/

5 ) 緑茶の品種識別マニュアル（野菜茶業研 究所)

http://vegetea.naro.affrc.go.jp/joho/ manual/chashikibetsu.pdf

6 ）緑茶の表示基準（社団法人日本茶業中央 会)

http://www.nihon-cha.or.jp/hyouji/ hyoujikijyun.pdf

7 ）食品表示と J A S 規格（農林水産省食品 安全局）

http://www.maff.go.jp/soshiki/syokuhin /heya/jasindex.htm 
別表 1 煎茶用品種（命名登録品種）

\begin{tabular}{|c|c|c|c|c|c|c|}
\hline 品種名 & 農林登録番号 & 来 歷 & 命名登録年 & 登䎑年" & 登録番号 & 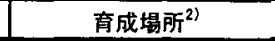 \\
\hline あさつゆ & 茶農林2号 & 宇浩在来摆英生 & 1953 & & & 茶業試験場 (金谷) \\
\hline みよし & 茶農林3号 & 于治在来理实生 & 1953 & & & 茶菜試験場 (金谷) \\
\hline さやまみどり & 茶農林5号 & 宇治在来程类生 & 1953 & & & 埼玉県立農試茶業支場 \\
\hline やぶきた & 茶農林6号 & 解岡在采程实生 & 1953 & & & 静岡県茶業詿験場 \\
\hline まきのはらわせ & 茶農林7号 & 解周在来摆实生 & 1953 & & & 静岡県茶業試医場 \\
\hline こやにし & 茶農林8号 & 宇治在来程实生 & 1953 & & & 静岡県茶業試験場 \\
\hline ろくろう & 茶農林9号 & 在采转 & 1953 & & & 静岡県茶業試験場 \\
\hline やまとみどり & 茶農林10号 & 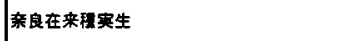 & 1953 & & & 奈良県農試茶業分場 \\
\hline なつみどり & 茶農林16号 & 劓周在来理实生 & 1954 & & & 茶業試験場（金谷） \\
\hline やえほ & 茶農林17号 & 用周在来提实生 & 1954 & & & 静岡県茶業試験場 \\
\hline はつみどり & 茶農林20号 & 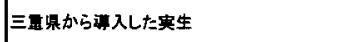 & 1954 & & & 鹿児島県茶羓試験場 \\
\hline おくむさし & 茶農林26号 & さやまみどりメやまとみどり & 1962 & & & 埼玉県茶業研究所 \\
\hline かなやみどり & 茶農林30号 & s $6 \times$ やぶきた & 1970 & & & 茶業試験場 (金谷) \\
\hline さやまかおり & 苏農林31昂 & やぶきた实生 & 1971 & & & 埼玉県茶業研究所 \\
\hline おくみどり & 茶農林32号 & や分きた×角在 16 & 1974 & & & 茶業試験場（金谷） \\
\hline とよか & 茶農林33号 & さやまみどりメやぶきた & 1976 & & & 埼玉県茶業試験場 \\
\hline おくゆたか & 茶農林34号 & (ゆたかみどり×F、NN8(たまみどり × S6) & 1983 & 1983 & 第455号 & 茶業試験場（金谷） \\
\hline めいりょく & 茶農林35号 & やぶきた ×Z1 & 1986 & 1987 & 第1388号 & 野菜·茶業試験場（金谷） \\
\hline ふくみどり & 茶農林36号 & 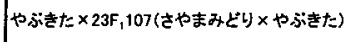 & 1986 & 1988 & 第1556号 & |埼玉県茶業試験場 \\
\hline しゅんめい & 茶農林37号 & ゆたかみどり XF、NNB & 1988 & 1990 & 第2159号 & 野菜·茶業試験場(金谷) \\
\hline みねかおり & 茶農林38号 & やぶきた×うんかい & 1988 & 1990 & 第2157号 & 宮崎県総眘試茶菜支場 \\
\hline みなみかおり & 茶農林39号 & やぶきた×宮A11 & 1988 & 1990 & 第2158号 & 宮崎県釉農試茶業支場 \\
\hline さえみどり & 茶農林40号 & やぶきだのあうつ & 1990 & 1991 & 第2881号 & 野菜·茶業試験場（松崎） \\
\hline ふうしん & 茶農林41号 & $\mathrm{Z} 1 \times$ かなやみどり & 1991 & 1993 & 第3697号 & 野菜·茶策試験場 (金谷) \\
\hline みなみさやか & 茶農林42号 & 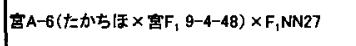 & 1991 & 1994 & 第3932号 & 宮崎県総農試茶業支埸 \\
\hline ほくめい & 茶農林43号 & さやまみどり×5507(やぶきた自然軍生) & 1992 & 1995 & 第4775号 & 埼玉県茶業試験場 \\
\hline りょうふう & 茶農林45号 & ほうりょく×やぶた & 1997 & 2001 & 第9204号 & 野菜·茶業試験場 (金谷) \\
\hline むさしかおり & 茶農林46昂 & さやまかおり × 硬枝轪心英生 & 1997 & 2001 & 第9306号 & 埼玉県茶業試験場 \\
\hline さきみどり & 茶農林47号 & F, NN27 X ME52 & 1997 & 2001 & 第9203号 & 宮崎県㥹農試茶業支場 \\
\hline はるみどり & 茶豊林48号 & かなやみどりメやぶきた & 2000 & 2003 & 第11102号 & 野莱·茶菜試験場(枕崎) \\
\hline そうふう & 茶農林49号 & やぶきだ×解涠 131 & 2002 & 2005 & 第12706号 & 野菜茶業研究所(金谷) \\
\hline さいのみどり & 茶農林50号 & さやまかおり実生 & 2003 & 2006 & 第13753号 & 塔五県農枌研葉業特産研究所 \\
\hline はるもえぎ & 茶農林51号 & F,NN27 × ME52 & 2003 & 2006 & 第13755号 & 宮畸県総農試茶菜支場 \\
\hline みやまかおり & 茶農林52号 & 京研 $283 \times$ 堵玉1 & 2003 & 2006 & 第13754号 & 宮崎県総農跔茶業支場 \\
\hline ゆめわかば & 茶農林53号 & やぶきた×婍五9㝍 & 2006 & 出願中 & & 埼玉県農捻研茶莱特産研究所 \\
\hline ゆめかおり & 茶農林54号 & さやまかおり×宮㽠8号 & 2006 & 出願中 & & 宮崎県総農試茶業支場 \\
\hline
\end{tabular}

1)登録年: 㮔苗法に基つく品種登䟿年

2)育成者権者は表 1 を参照 
別表 2 煎茶用品種（登録品璉）

\begin{tabular}{|c|c|c|c|c|}
\hline 品種名 & 来 歴 & 登録年") & 登録番号 & 育成者権者名 \\
\hline 星野緑 & 福咸県在来種 & 1981 & 第71号 & 井上十二生 \\
\hline 司みどり & 静周抙在来種 & 1984 & 第511号 & 山崎裕司 \\
\hline たかねわせ & やぶきた自然实生 & 1985 & 第898号 & 村松穗一 \\
\hline さとう早生 & 安倍1号自然实生 & 1986 & 第1025号 & 佐藤光輝 \\
\hline おくひかり & やぶきた×静Cy225 & 1987 & 第1387号 & 静岡県 \\
\hline いなぐち & や分きた自然英生 & 1988 & 第1676号 & 稲口勝利 \\
\hline さわみずか & やぶきたメふ心はどり & 1995 & 第4292号 & 静岡県 \\
\hline みねゆたか & やぶきた枝変わり & 1996 & 第4835号 & 松下栄市 \\
\hline 松寿 & くりたわせ枝变わり & 1996 & 第4952号 & 昖下栄市 \\
\hline 摩利支 & 杉山八里瑟自然实生 & 1996 & 第4953号 & 山森美好·山森理佐雄 \\
\hline みえ緑萌1号 & やぶきた自然案生 & 1996 & 第4954号 & 三重県 \\
\hline あさのか & やぶをた XCp1昂 & 1996 & 第5013号 & 庇児島県 \\
\hline 藤かおり & 觧的䧴131 ×やふふぶきた & 1996 & 第5072号 & 森園市二·小柳三墀 \\
\hline 山の息吹 & やぶきた自然实生 & 1997 & 第5430号 & 静岡県 \\
\hline さがらひかり & やぶきた自然实生 & 1998 & 第6684号 & 中村孫一 \\
\hline さがらみどり & やぶきた自然英生 & 1998 & 第6685号 & 中村孫一 \\
\hline 香駿 & くらさわ×かなやみどり & 2000 & 第8131号 & 静岡県 \\
\hline さがらかおり & やぶきた自然荑生 & 2000 & 第8132号 & 中村孫一 \\
\hline さがらわせ & やぶきた自然英生 & 2000 & 第8133号 & 中村孫一 \\
\hline みどりの星 & やぶきた自然実生 & 2001 & 第9305号 & 中村孫一 \\
\hline りょくふう & 自然交雓实生 & 2002 & 第9652号 & 白鳥俊男 \\
\hline つゆひかり & 觧 $7132 \times$ あさつゆ & 2003 & 第11103号 & 静岡県 \\
\hline みえうえじま & 在来英生 & 2003 & 第11368号 & 上嶋 親 \\
\hline きら香 & やぶきた枝变わり & 2006 & 第14307号 & 竹内清美· 竹内忠義 \\
\hline
\end{tabular}

1)登録年:種苗法に基づく品種登録年 
別表 3 金炒り茶・玉緑茶用品種

\begin{tabular}{|c|c|c|c|c|c|c|}
\hline 品種名 & 農林登録番号 & 来 歴 & 命名登録年 & 登録年 ${ }^{1)}$ & 登録番号 & 育成場所 ${ }^{2)}$ \\
\hline たまみどり & 茶農林4号 & 宇治在来種实生 & 1953 & & & 茶業試験場(金谷) \\
\hline たかちほ & 茶農林11号 & 宮崎県在来種实生 & 1953 & & & 宮崎県総農試茶業支場 \\
\hline いずみ & 茶農林24号 & べにほまれの实生 & 1960 & & & 九州農業試験場 \\
\hline やまなみ & 茶農林27号 & 中国湖北省入实生 & 1965 & & & 宮崎県総農試茶業支場 \\
\hline うんかい & 茶農林29号 & たかちほメ宮F、 9-4-48 & 1970 & & & 宮崎県棇農試茶業支場 \\
\hline みねかおり & 茶農林38号 & やぶきたメうんかい & 1988 & 1990 & 第2157号 & 宮崎県絰農試茶業支場 \\
\hline
\end{tabular}

1) 登録年:種苗法に基つく品種登録年

2)育成者権者は表1を参照

別表 4 玉露・てん茶用品種

\begin{tabular}{|c|c|c|c|c|c|c|}
\hline 品種名 & 農林登録番号 & 来 歴 & 命名登録年 & 登録年 ${ }^{1)}$ & 登録番号 & 育成場所 \\
\hline あさぎり & 茶農林18号 & 宇治在来種実生 & 1954 & & & 京都府立茶業研究所 \\
\hline きようみどり & 茶農林19号 & 宇治在来種実生 & 1954 & & & 京都府立茶業研究所 \\
\hline ひめみどり & 茶農林23号 & 福岡在来種实生 & 1960 & & & 九州農業試験場 \\
\hline 寺川早生 & & 宇治在来㮒实生 & & 1990 & 第2092号 & 寺川俊男 \\
\hline 成里乃 & & 宇治在来種実生 & & 2002 & 第10751号 & 堀井信夫 \\
\hline 奥の山 & & 宇治在来種実生 & & 2002 & 第10752号 & 堀井信夫 \\
\hline 凬春 & & さみどり自然交雓英生 & & 出願中 & & 京都府立茶業研究所 \\
\hline 展茗 & & さみどり自然交就英生 & & 出願中 & & 京都府立茶業研究所 \\
\hline
\end{tabular}

1)登録年: 種苗法に基づく品種登録年

別表 5 紅茶用品種

\begin{tabular}{|c|c|c|c|c|c|c|}
\hline 品種名 & 農林登録番号 & 来 歴 & 命名登録年 & 登録年 ${ }^{1)}$ & 登録番号 & 育成場所 ${ }^{2}$ \\
\hline ベにほまれ & 茶農林1号 & 多田系インド刑入垪实生 & 1953 & & & 茶業試験場 (金谷) \\
\hline いんど & 茶農林12号 & インド雑種实生 & 1953 & & & 鹿児島県茶業試験場 \\
\hline はつもみじ & 茶農林13号 & $\mathrm{Ai} 2 \times \mathrm{NkaO} 5$ & 1953 & & & 鹿児島県茶業試験場 \\
\hline ベにたちわせ & 茶農林14号 & $\mathrm{Ai} 2 \times \mathrm{NkaO} 1$ & 1953 & & & 鹿児島県茶業試験場 \\
\hline あかね & 茶農林15号 & $\mathrm{Ai} 2 \times \mathrm{NkaO}_{3}$ & 1953 & & & 鹿児島県茶業試験場 \\
\hline ベにかおり & 茶農林21号 & $\mathrm{Ai} 21 \times \mathrm{NkaO} 3$ & 1960 & & & 庵児島県茶業試験場 \\
\hline ベにふじ & 茶農林22号 & ベにほまれ ×C19 & 1960 & & & 茶業試験場 (金谷) \\
\hline さつまべに & 茶農林25号 & NkaO3 $\times$ Ai18 & 1960 & & & 鹿児島県茶業試験場 \\
\hline ベにひかり & 茶農林28号 & べにかおり ×CN1 & 1969 & & & 茶業試験場（椌崎） \\
\hline ベにふうき & 茶農林44号 & べにほまれ ×枕Cd86 & 1993 & 1995 & 第4591号 & 野菜·茶業試験場（枕崎） \\
\hline
\end{tabular}

1)登録年: 種苗法に基つく品種登録年

2) 育成者権者は表 1 を参照 
別表 6 中間母本登録品種

\begin{tabular}{|c|c|c|c|c|c|c|c|}
\hline $\begin{array}{l}\text { 登録番号 } \\
\text { (品種名) }\end{array}$ & 出願時の名称 & 来 歴 & 命名登録年 & 登録年 ${ }^{1)}$ & 登録番号 & 育成場所 ${ }^{2)}$ & 主要特性 \\
\hline 茶中間母本農 1号 & チャツバキ1䒓 & きやまかおり×ヤブッパキ & 1988 & 1992 & 第3047号 & 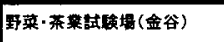 & 勈病虫性 \\
\hline 茶中間母本農2号 & IRB89-15 & やぶきた伎射昹突然变異 & 1994 & 1998 & 第6449号 & 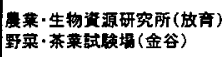 & 自示和合性 \\
\hline 茶中間母本農3号 & MAKURA 1㝍 & インドからの山洅生 & 1998 & 2002 & 第10244号 & 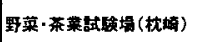 & 高タンニン·高力フェイン・花香 \\
\hline 茶中間母本農4号 & KMB & 金Ck17×さやまかおり & 2004 & 出願中 & & 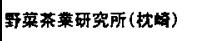 & クワシロカイガラムシ振抗性 \\
\hline 余中間母本農5号 & KM62 & 金Ck17×さややまかおり & 2004 & 出願中 & & 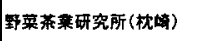 & クワシロカイガラムシ抵抗性 \\
\hline 茶中間母本農6号 & F95181 & 夘エンシス ×おくむさし & 2004 & 出願中 & & 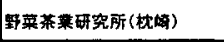 & 高アントシアニン \\
\hline
\end{tabular}

1)登録年:種苗法に基了く品種登録年

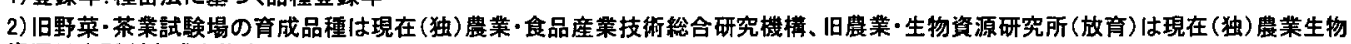
資源研究所が育成者権者

別表 7 命名登録・品種登録をされなかった主な品種

\begin{tabular}{|c|c|c|c|c|}
\hline 品種名 & 用 途 & 来 歴 & 育成年 & 育成場所 \\
\hline ほうりょく & 槊菜 & 多田系印雓の实生 & 1956 & 静岡県茶業試験場 \\
\hline するがわせ & 斯茶 & やぶきた自然英生 & 1962 & 静岡県茶業試験場 \\
\hline ふじみどり & 喓茶 & 不明 & 1962 & 静岡県茶業試験場 \\
\hline くりたわせ & 葆茶 & 静岡在来实生 & 1966 & 鹿児島県茶業試験場 \\
\hline ゆたかみどり & 想苏 & あさつゆ自然实生 (系䃄名:Y2) & 1966 & 茶業試験場(金谷) \\
\hline やまかい & 前茶 & やぶきた自然実生 & 1967 & 静岡県茶業試験場 \\
\hline くらさわ & 煎 & やぶきた自然実生 & 1967 & 静岡県茶業試験場 \\
\hline おおいわせ & 盟茶 & やえ゙はメやぶきた & 1976 & 静岡県茶業試験場 \\
\hline ごこう & 王露·てん来 & 宇治在来実生 & 1954 & 京都府立茶業研究所 \\
\hline うしひかり & 玉露·てん荣 & 京都在来理 & 1954 & 京都府立茶業研究所 \\
\hline あさひ & 玉五星·てん萧 & 宇治在来実生 & 1954 & 京都府立茶業研究所 \\
\hline こまかげ & 玉露·てん莱 & 宇治在来实生 & 1954 & 京都府立茶業研究所 \\
\hline さみどり & 玉露·てん来 & 京都在来種 & 1954 & 京都府立茶業研究所 \\
\hline おぐらみどり & 王露·てん茶 & 京都在来理 & 1954 & 京都府立茶業研究所 \\
\hline うじみ゙り & 玉露·てん茶 & 宇治在来実生 & 1985 & 京都府立茶業研究所 \\
\hline からへに & 紅菜 & 中国湖北省英生 & 1956 & 静岡県茶業試験場 \\
\hline ただにしき & 紅茶 & 多田系イント灣入種英生 & 1958 & 静岡県茶業試験場 \\
\hline ベにつくば & 紅莱 & 茨城県在来種 & 1958 & 真壁地区農業改良普及所 \\
\hline
\end{tabular}

